\title{
Grief for the Living: Appropriating the Irish lament for songs of emigration and exile
}

\author{
Gerald Porter
}

Lillis Ó Laoire ${ }^{1}$ has shown how, as the Irish language today signifies identity less and less, Gaelic forms of expression have paradoxically come to signify more. Irish has come to occupy a liminal space where both Irish speakers and those who have only a few words at their command share a range of forms of cultural expression. ${ }^{2}$ In this study of some extensions of the Irish lament into English, such as songs of emigration and exile, I suggest that, in spite of the threat to Irish as an expressive medium of everyday speech, these songs can be regarded as important, and contemporary, examples of the 'lost voices' of feeling.

The lament in Irish drew on a long tradition. In Classical Greece, emotional appeals to those who grieved (paramythia), consoling them for their loss, were part of the apparatus of traditional rhetoric. Patricia Lysaght says that in Ireland a lament was not simply a conventional performance but above all 'a means of expressing a sense of personal...loss, grief, love, sorrow and bitterness'. ${ }^{3}$ In addition, Ó Laoire has shown that cumha (grief, longing for what was lost) was part of a web of customs and beliefs accepted as entirely natural. ${ }^{4}$ The dead have often been described through metaphors of the journey such as 'the departed' and 'passing over'. Since those who left Ireland were often never seen or heard from again, songs of emigration and exile drew on these readily available discourses of grieving.

Sigmund Freud distinguished between two responses to loss: melancholia and mourning; the former he saw as a pathological reaction to loss involving identification with the lost object, while the latter was a healthy condition of coming to terms with it. ${ }^{5}$ Keening corresponded to the second of these- the

\footnotetext{
1 I am very grateful to Dr Ó Laoire for his insights and discussions; my debt to his work is evident at many points in this paper.

2 Porter, Gerald 2008, 'Code-switching and empowerment in the Macaronic Irish lyric', in Übersetzungstheorie, Fachsprachen und Mehresprachigkeit [Terminology, Translation Theory and Multilingualism], Special Number: Language and Diversity, Studiengruppe für Übersetzungstheorie, Fachsprachenforschung und Mehresprachigkeit, Vaasa, pp. 257-67.

3 Lysaght, Patricia 1997, 'Caoineadh os Coinn Coirp. The lament for the dead in Ireland', Folklore, vol. 108, pp. $65-82$, at pp. 66,69 .

4 Ó Laoire, Lillis 2005, On A Rock in the Middle of the Ocean. Songs and singers in Tory Island, Cló IarChonnachta, Indreabhan, Conamara, Ireland, pp. 183, 185.

5 Freud, Sigmund 1959, 'Mourning and melancholia', in Collected Papers. Volume 4, Edited by Ernest Jones, Translated by Joan Riviere, Basic Books, New York, pp. 152-70.
} 
immediate response to a death. It was performed in the presence of the dead, since a folk belief maintained that the dead person could continue to hear mortals until earth had been thrown on the coffin. It often took a very simple form, since emphasis in the Gaelic tradition was laid not on improvisation but on accurate repetition, and, by spontaneously expressing cumha, providing a measure of release. ${ }^{6}$ It was not purely verbal, however, but a response to personal loss played out simultaneously through the space of the body and the space of the mind. In the words of Lauri Honko:

[I]t is absolutely misguided to approach laments via a perusal of their texts. The reader who is unfamiliar with the vocabulary of the laments is left utterly bewildered after only a few verses: he can only vaguely make out the sense of the poem. One comes to the language of ritual lament with an entirely different attitude if one has listened to the wailings of a Karelian woman in an authentic performance environment, in a graveyard, at the foot of a cross, or in the house of a bride at the moment of her departure to the [bride]groom's farm. ${ }^{7}$

As is well known, in Ireland a death was often also accompanied by a quite different form of grieving: the often riotous nature of the funeral wake. Such behaviour was considered by outsiders (such as members of the English Ascendancy) to be quite inappropriate to the presence of death, but, in Roy Foster's words, 'the Irish affected to dwell in a different abstract world', where death was often referred to mockingly. ${ }^{8}$ In Bakhtinian terms, humour makes death easier to live with; in Freudian terms, it makes grieving a whole and healthy practice. ${ }^{9}$ At a moment when nature has asserted its supremacy over culture, it is the momentary return of the repressed. In the doubleness of humour and terror, we perceive the kind of ambivalence that is part of the process of confronting the prospect of one's own death.

Laments in Ireland took many more forms than mourning a death: they were sung on conscription into the army, on the field of battle and during evictions, in addition to those sung on emigrating, which are the subject of this paper. In Eastern Europe, from Karelia to Greece, they were also sung to brides before their wedding: 40000 such songs, known as dainas, have been documented in Latvia alone. ${ }^{10}$ At funerals, formal laments - which have remained a supreme

6 Ó Laoire, On A Rock in the Middle of the Ocean, pp. 91, 176, 215.

7 Quoted in Nenola, Aili 2002, Inkerin itkuvirret [Ingrian Laments], SKS, Helsinki, p. 75.

8 Foster, Roy F. (ed.) 1989, Oxford History of Ireland, Oxford University Press, Oxford, p. 94.

9 Bakhtin, Mikhail 1984, Rabelais and His World, Translated by Hélène Iswolsky, Indiana University Press, Bloomington, p. 94; Freud, 'Mourning and melancholia', pp. 152-70.

10 Beaton, Roderick 1980, Folk Poetry of Modern Greece, Cambridge University Press, Cambridge, p. 97; Vike-Freiberga, Vaira 1991, 'The poppy blossom from my native land', in Luisa Del Giudice and Gerald Porter (eds), Imagined States. Nationalism, utopia and longing in oral cultures, Utah University Press, Logan, Ut., pp. 193-213. 
Gaelic genre from earliest times - began in the eighteenth century to be seen as specifically asserting death's dominance over life, and the singing of selfcomposed songs, often tragic but also including love songs, gradually replaced keening. There were literary examples such as Eilean O'Leary's famous lament for her murdered husband ('Caoineadh Airt Ui Laoghaire' ['Lament for Art Ó Laoghaire']), with its unforgettable image of the horse returning without its rider, or the grief expressed at the beginning of the twentieth century by a father for his daughter. ${ }^{11}$ Such poems and songs were thus an act of healing, a return to the moment of loss.

\section{Keening and Authority}

The moment of passing between life and death has often been an arena for the assertion of power, most spectacularly, of course, in ancient Egypt. Because the practice of lamenting coincided with that moment, it often led to clashes with authority figures such as the priest. The singing of laments was strongly opposed as unchristian by Calvinists and Lutherans in German-speaking Europe, and by Catholic priests in Provence, where two choirs of young girls were prevented from following their tradition of chanting dirges alternately to the accompaniment of instruments. ${ }^{12}$ One result of this may have been the creation of a lament style in English. Ironically, this was also the position of Catholic bishops in Ireland from the seventeenth to the twentieth centuries: in 1748, for example, 'the heathenish customs of loud cries and howlings at wakes and burials' were condemned by the Bishop in Leighlin, near Carlow, on the quite inaccurate grounds that 'no such practice is found in any other Christian country'. ${ }^{13}$ The increase in church building that followed the Catholic Emancipation Act of 1830 brought further restrictions on keening on church land and on occasions when priests were present. As in Hungary, Corsica and German-speaking Europe, ${ }^{14}$ in Ireland the bourgeoisie, who preferred to use funerals as an opportunity for display and ceremony, began in the nineteenth century to represent keening as pagan, superstitious and unacceptably dramatic. Hence keening in recent years has been policed not only by priests but often also by the mourners themselves, as Lillis Ó Laoire has documented: as late as 1990 the sister of a man who had drowned while swimming started to chant his

11 Kinsella, Thomas (trans.) 1981, An Duanaire. 1600-1900. Songs of the dispossessed, Dolmen Press, Portlaoise, Ireland, pp. 200, 258.

12 Ling, Jan 1997, History of European Folk Music, Translated by Linda and Robert Schenck, University of Rochester Press, Rochester, NY, pp. 59, 61; Martinengo-Cesaresco, Countess n.d. [1914], Essays in the Study of Folk-Songs, Dent, London, p. 270.

13 Quoted in Lysaght, 'Caoineadh os Coinn Coirp', pp. 66-7.

14 Ling, History of European Folk Music, pp. 59, 61. 
name loudly at his funeral. His relatives persuaded her to stop what was felt to be an embarrassing show of emotion and a throwback to an Ireland that had been left behind. ${ }^{15}$

Even the singing of laments has frequently led to conflict. Ó Laoire describes a classic example of such hegemonic control at the funeral of a young girl who had been swept away by a tsunami on Tory Island off the north coast of Ireland. Her grandmother struck up a lament at the funeral and continued until she was asked to 'show some sense' (ciall a bheith aici). At the funeral of the greatly admired singer Joe Heaney in County Galway in 1984, the singer Maíre Davitt was refused permission by the priest to sing a lament in the church unless it was a sacred one. Ó Laoire suggests that laments were sometimes sung in English as a way of escaping censure by priests and others. ${ }^{16}$

All the singers I have mentioned so far have been women: in MartinengoCescaresco's words, 'the Irish keeners are invariably women, as also are all the continental dirge-singers of modern times' ${ }^{17}$ The role of women as lamenters, with authority figures like priests playing only a peripheral role, has been well documented in many cultures. Keening was used as an instrument of empowerment by women across Europe: Elias Lönnrot and others were terrified at hearing women's outbursts of grief, some of which, such as the laments of the Ingrians, have been collected and published. ${ }^{18}$ They belong to what Andreas Huyssen calls a 'post modernism of resistance' in which subaltern groupsparticularly women - speak using the materials of their marginalisation. ${ }^{19}$ In Ireland, keening by women took place alongside, and often in competition with, church rituals for the dead, much as the present-day midwife - still representing a link with traditional female birthing practices - works in tandem with the obstetrician. This central role of women has been carried over into the songs of emigration and exile.

\section{The Lament and Songs of Emigration}

By the nineteenth century, 'sorrowful songs' were gradually taking the place of keening as an expression of grief in Ireland. This was largely a response to

15 Ó Laoire, On A Rock in the Middle of the Ocean, pp. 273-4.

16 Ibid., pp. 150, 273-4, 276.

17 Martinengo-Cesaresco, Essays in the Study of Folk-Songs, p. 271. See also Honko, Lauri, Timonen, Senni, Branch, Michael and Bosley, Keith (eds) 1993, The Great Bear. A thematic anthology of oral poetry in the FinnoUgrian languages, SKS, Helsinki, pp. 570-1.

18 Ling, History of European Folk Music, p. 60; Nenola, Inkerin itkuvirret.

19 Quoted in Wilson, Elizabeth 2009, 'Fashion and postmodernism', in John Storey (ed.), Cultural Theory and Popular Culture. A reader, Fourth edn, Pearson, Harlow, UK, pp. 444-55, at p. 451. 
the historical moment. Laments were never restricted only to rituals for the dead, and now they were being adapted to express the collective trauma of the tensions and tragedy of emigration. ${ }^{20}$

As a result of mass emigration, the leaving ceremony later known as the 'American Wake' - singing in the absence of the corpse-became established. Arthur Schrier traces this funeral without a body back to the early nineteenth century, and emphasises the role of singing: 'Frequently the songs sung were also sad. They were generally ballads which told of the difficulties of parting, the loneliness of parents and the hardships of emigrant life. ${ }^{21}$ These features are rarely found in transportation songs, but are associated with the heavy emigration from Ireland from the time of the Famine right up until the 1960s. This huge movement of population-four-fifths of whom were Catholicbecame a leading source of new songs.

Lillis Ó Laoire describes how those leaving would often be accompanied by a large entourage, known as the 'convoy', as if at a funeral. He quotes an account from 1942 that explains the convoy as taking place

the night before someone goes to America. It is a remarkable gathering. It has the joy of a wedding and the cumhaidh [mourning] of death. At the beginning of the night, you can hardly see the shadow of cumhaidh. But after midnight, it will begin to become apparent. And by daybreak, I may say, nothing else is present. ${ }^{22}$

The balance between humour and sorrow is, of course, an almost essential feature of the traditional wake. The American variety also sought to express social values and concerns as well as familial emotions. Songs were 'designed to obscure the often mundane or ambiguous realities of emigration, to project communal sorrow and anger on the traditional English foe, to impress deep feelings of grief, guilt and duty on the departing emigrants, and to send them forth as unhappy but faithful and vengeful "exiles"”. ${ }^{23}$

John Ó Duibheanaigh, a member of a well-known family of storytellers and musicians, recalled in an interview the sense of loss in the 1920s when someone left Tory Island. He called it 'cumha [grief] for the living':

Someone who went to America, your cumha for him, and his for you were increasing...because, as I said, the person who went to America had an idea that if he ever came back it would be years and years, and

20 Ó Laoire, On A Rock in the Middle of the Ocean, pp. 155, 235, 272.

21 Schrier, Arthur 1958, Ireland and the American Emigration 1850-1900, University of Minnesota Press,

Minneapolis, pp. 85, 89.

22 Quoted in Ó Laoire, On A Rock in the Middle of the Ocean, p. 253.

23 Miller, Kerby 1985, Emigrants and Exiles, Oxford University Press, Oxford, p. 565. 
that his father, perhaps, would be dead and his mother dead, even if he did return, and those were kinds of cumha. And that cumha is intimately connected with, do you understand, again, the best songs...that we have; they were made because of cumha and uaigneas [loneliness]. ${ }^{24}$

These two concepts - grief and loneliness - were key elements in the habitus (or system of group beliefs and attitudes) of the community and were most fully realised in song. I suggest that the emigration songs that are sung everywhere in Donegal and the whole north coast often have the same dialectical relation to these songs of loss precisely because they include elements of the lament.

The earliest emigration songs appeared in the period following 1830. Joep Leerssen calls this period the Sattelzeit- 'the saddle period'-because it was a period of cultural transfer in Ireland between the enclosed Gaelic tradition without a large-scale system of communication and the urban, English-speaking print culture in the early nineteenth century. ${ }^{25}$ Emigration songs were also sung increasingly in English so that singers could escape the more demanding formal requirements of songs in Irish. ${ }^{26}$

He see, instead of colonialist appropriation, the urbanisation and anglicisation of Gaelic culture as a regaining/recovery of public space comparable with Daniel O'Connell's reclamation of places like Tara and Cashel, which until then had been monopolised by the colonial elite, by holding huge rallies there. Anglophone culture brought more social control and individualism but also greater social mobility and above all access to the printed media. As a result, the dirge shed its role in popular texts as an icon of the subordination of the Irish and became transformed into the voice of the migrant. One reason for this was that England has a weak tradition of laments: only one formal example survives, the famous Northumberland 'Lyke Wake Dirge' from before the seventeenth century; however, as English began to be the (imposed) language of cultural expression in both Ireland and Scotland, particular songs took on many of their features. James Porter and Herschel Gower have shown how Scottish singers like Jeannie Robertson projected the idea of the lament on to their big ballads, the 'muckle sangs ${ }^{\prime},{ }^{27}$ and this transference of the charge that keening has always been felt to bear is found right across Europe.

At the same time, many features of Irish song - internal rhymes, the come-allye form, the relative rarity of narrative and the presence of Irish or Anglo-Irish words (such as 'Erin' or mavourneen asthore: 'my love, my treasure') - remained

\footnotetext{
24 Ó Laoire, On A Rock in the Middle of the Ocean, p. 175.

25 Leerssen, Joep 2002, Hidden Ireland, public sphere, Research Papers in Irish Studies, Arlen House, Galway, pp. 12-13.

26 Ó Laoire, On A Rock in the Middle of the Ocean, p. 150.

27 Porter, James and Gower, H. (eds) 1995, Jeannie Robertson. Emergent singer, transformative voice, Tuckwell Press, East Linton, Scotland, p. 300.
} 
prominent in the English songs. As a result of this interactive process, while there were fewer speakers, Irish gradually became more of a presence in the oral culture of those - today numbering an estimated 80 million - who have always lived in the diaspora.

Cheap paper and the invention of the rotary press in 1811 meant that there were now numerous broadside printers, in Dublin, Cork, Belfast and elsewhere, to disseminate these new songs. It is not surprising that many of the emigration songs that were sung at that time established a template that was based on the lament. ${ }^{28}$ The repetitive, intertextual nature of the emigration song, the final farewell to the grieving parents and the leave-taking from the beloved native land had obvious links with the keening tradition.

During the period before cheap air travel became available, there was a feeling that when someone left for Australia, it was the last anyone would see of them. A journey there or to North America was often seen as 'tantamount to death'. ${ }^{29}$ It has been estimated that of the 100000 emigrants to Canada alone, 40000 died, 17000 of them during the voyage and another 23000 shortly after arrival. It was said that you could have walked dry-footed to America on the bodies of those who had died on the voyage. Significantly, it was at this time (1833 onwards) that the term 'coffin ships' came into use to describe the overloaded and unseaworthy vessels on the Atlantic route. ${ }^{30}$ Geordie Hanna of County Tyrone expressed it vividly in this stanza of 'Erin's Lovely Home', which perhaps dates from the 1840s:

We hadn't been long sailing till fever it seized our crew,

Falling like the autumn leaves and overboard were threw [sic];

The ocean waves they rolled o'er our graves, our bed's the ocean foam,

Our friends may mourn for we'll ne'er return to Erin's Lovely Home. ${ }^{31}$

This stanza gives a good idea of the pervasive melancholy of this song, with its biblical intertext of human lives falling like leaves in the autumn and the idea of the ocean as a vast graveyard, a passage to the other world, like the River Styx.

\footnotetext{
28 Of the 66 songs relating specifically to emigration in Edwards (Edwards, Ron 1987, The Convict Maid. Early broadsides relating to Australia. Part 1, Rams Skull Press, Kuranda, Qld; Edwards, Ron 1988, The Transport's Lament. Early broadsides relating to Australia. Part 2, Rams Skull Press, Kuranda, Qld) and Anderson (Anderson, Hugh [ed.] 2000, Farewell to Judges and Juries. The broadside ballad and convict transportation to Australia, 1788-1868, Red Rooster Press, Hotham Hill, Vic.), more than half show features of the lament, and more than one-quarter have the word in their title.

29 Ó Laoire, On A Rock in the Middle of the Ocean, p. 242.

30 Woodham Smith, Cecil 1964, The Great Hunger, Four Square Books, London, p. 234; Harte, Frank 2004, The Hungry Voice. The song legacy of Ireland's great hunger, [CD: HBCD 0034], Humming bird Records, Dublin, track [25]; Compact Oxford English Dictionary 1991, Second edn, Clarendon Press, Oxford, p. 282.

31 Moulden, John 1994, Thousands are Sailing. A brief song history of Irish emigration, Ulstersongs, Portrush, Northern Ireland, p. 30.
} 
In particular, lines on the real danger of the sea crossing - a common subject of laments $^{32}$ - often accompanied the emotion felt by each emigrant at the wake, as in this broadside from Newcastle in the north of England:

Go where I may, nor billows, rocks, nor wind,

Can add of horror to my tortured mind..$^{33}$

The sea crossing was in other respects too a kind of journey through hell (katabasis). The fever mentioned in the first line of 'Erin's Lovely Home' was typhus, which spread easily among the passengers and crew in the crowded conditions on board. In those conditions, songs of exile functioned as close relatives of the lament, with émigrés as the 'walking dead'. In 'Three Leaves of Shamrock', for example, a pastiche of Thomas Moore published in Belfast as a broadside about 1900 but perhaps originally written in the United States, a woman begs a departing sailor to carry three shamrock leaves to her brother in America, and pass on her dead mother's appeal that he will return if he is still alive:

'My darling son come back to me', she often used to say,

And saying so she sickened, and soon was laid away:

Her grave I watered with my tears, and there those flowers grew,

Dear brother, they were all I had, and these I sent to you. ${ }^{34}$

'Three Leaves of Shamrock', with all its sentimental debt to Thomas Moore, functions like the Eastern European laments described by Lauri Honko, which call on the departed (the double meaning is intentional) to end their restless wandering and return, either in the form of a heroic homecoming or as a ghostly visitation..$^{35}$ The shamrock acts as an instrument of intercession. Within this tradition they can be seen as songs of loss, songs of a people unsettled, whose lives have been ruptured and have suffered a kind of 'little death'.

The process of cultural transfer moved rapidly and, by the middle of the nineteenth century, Protestant songs too had adopted the features of the Catholic lament. One of the earliest examples is 'The Transport's Lament', ${ }^{36}$ where the singer opens with a circumstantial description of how he was caught poaching and sentenced to 14 years in Van Dieman's Land:

On the 15th of September we sailed from Chatham quay,

For full five months and upwards boys we ploughed the raging sea,

32 Martinengo-Cesaresco, Essays in the Study of Folk-Songs, p. 286.

33 Anderson, Farewell to Judges and Juries, p. 456.

34 Ó Cróinin, Dáibhí (ed.) 2000, The Songs of Elizabeth Cronin, Four Courts Press, Dublin, p. 284 [Punctuation added].

35 Honko et al., The Great Bear, pp. 565-70.

36 Cork broadside, c. 1830. 
Neither land nor harbor could we see-believe me it's no lie,

But around us one black water and over us a blue sky.

Young men all beware lest you draw into a snare.

There is an almost obligatory reference here to the carefree childhood spent in the land that is being left behind, and a tableau of grieving parents:

I often looked behind me towards my native home,

That cottage of contentment the place I'll ne' er see more,

Nor yet my poor old father who tore his old grey hair,

Likewise my tender mother those arms that did me bear.

Young men all beware lest you draw into a snare. ${ }^{37}$

After the success of the Irish-American song 'Mother Machree' in 1910, the Irish mother standing weeping on the dock (or today at the airport departure gate) to mourn the parting son became a standard trope in Irish emigration songs.

Many of these songs are very precise in their accounts of the circumstances leading up to the exile, as in this version of 'Erin's Lovely Home' in the repertoire of four members of the Butcher family from North Derry:

My father sold his second cow and borrowed twenty pound,

All in the merry month of May we sailed from Derry quay,

There were thousands more along the shore all anxious they might roam

To leave the land where we were reared called Erin's lovely home. ${ }^{38}$

The anxiety expressed in the third line, however, suggests a darker intertext. In many songs there is a coda where the emigrant speaks as if he himself were one of the 'walking dead':

Mourn not for me, my mother dear,

And father, do not grieve. ${ }^{39}$

These two songs - 'Erin's Lovely Home' and 'The Transport's Lament' - from two very different Irish communities, deal in the same way with the cultural transfer of the lament. When separated from the dynamic of a performance in a community in Cork or Donegal, where migration has been a fact of life for nearly 200 years, such songs are often considered embarrassingly sentimental today. By restoring their link with the Gaelic lament, they can be recovered as responses to loss, sung by marginal figures testifying to their own occluded history. Emigration, whether as a result of famine, eviction or stealing a bolt

37 Edwards, The Transport's Lament, p. 98 [Original punctuation].

38 Shields, Hugh 1981, Shamrock, Rose and Thistle. Folk singing in North Derry, Blackstaff Press, Belfast, p. 76.

39 Moulden, Thousands are Sailing, p. 20. 
of cloth, can fairly be ranked alongside the institution of slavery as a primary source of trauma, both individual and collective, for those who suffered it. Being forced to leave one's native land and the subsequent sea crossing have been known to cause serious traumatic symptoms since the seventeenth century. The song topos of wishing to return to a lost and idealised past has been described in migration literature as 'cultural nostalgia' $;{ }^{40}$ however, the term is not a trivial cliché. As Ó Laoire puts it, 'nostalgia [coined 1688, nostos, return to native land, and algon, grief] was thought to be a physical disease rather than a psychological state. It was thought to affect people who were away from their native countries to the extent that it sometimes caused death. ${ }^{\prime 41}$ As the powerful acts of recall in the songs of Geordie Hanna and the Butcher family show, nostalgia is crucially related to the process of grieving. It functions as what Toni Morrison calls in Beloved 'rememory' - an act of healing, a return to the time before the moment of loss. ${ }^{42}$

With Ireland's recession the most serious in the European Union after Greece's, not only are Poles and Latvians returning to their home countries, but once again young Irish in Donegal, Derry and Galway are leaving. These migrant songs continue to be written today, often under the influence of romantic nationalism, in Irish communities in Australia and elsewhere, and have regularly been mistaken for traditional compositions. ${ }^{43}$ In Newfoundland, for example, where the Irish diaspora is strong, songs like 'That Dear Old Land', 'Erin's Green Shore' and 'Misty Morning Shore' are still composed and performed in traditional style; ${ }^{44}$ however, these songs can usually be distinguished from the early songs by their upbeat tone: understandably, during the Kennedy years in the United States, for example, they emphasised the advantages that settling in a land of opportunity offered.

John Moulden has called into question the assumption that all emigration songs were filled with melancholy: he suggests that it was a projection by those who remained, and that those who survived the voyage took a much more cheerful view of it on their arrival..$^{45}$ This is particularly true of the flourishing tradition of such songs along the North American seaboard. The involvement of those who remained is precisely that aspect which drew, like a bereaved family, on the consolatory role of grieving. Not unnaturally, the sea crossing was symbolically associated with dying: the possibility of shipwreck, the liminality of the sea

\footnotetext{
40 Svensson, Anette 2010, A Translation of Worlds, University of Umeå, Umeå, Sweden, p. 86.

41 Ó Laoire, On A Rock in the Middle of the Ocean, p. 193.

42 Morrison, Toni 1997, Beloved, Vintage, London, p. 35.

43 Moulden, John 2006, The printed ballad in Ireland, Unpublished thesis, National University of Ireland, Galway, pp. 387-411.

44 Greenleaf, E. B. and Mansfield, G. Y. (eds) 2004, Ballads and Sea Songs of Newfoundland, Memorial University Folklore and Language Publications, St Johns, Newfoundland, pp. 142-5; Irish Descendants 1991, Misty Morning Shore, [Audio cassette: FCP 106], First City Productions, St Johns, Newfoundland.

45 Moulden, The printed ballad in Ireland, 390.
} 
boundary and the difficulty of return all intersected with the preoccupations of keening mourners contemplating death. At the same time, exile was associated with a search for identity and the spirit of the nation. In this way songs of exile became the mouthpiece of a politics of feeling that would not be structured purely in terms of nationalism and oppression. In Ó Laoire's words:

[T] he whole narrative web is a symbol of the tensions and tragedy of emigration, of the expression of family bonds and the dialectical relation to marital ties, of island ideology, of the cumha and uaigneas [sorrow and loneliness] inherent in the human condition, all of it situated in a common Northern European cultural framework. ${ }^{46}$

It is this complexity that places Irish emigration songs among the greatest expressions of human loss.

\section{Bibliography}

Morton, A. L. 1974, People's History of England, Lawrence \& Wishart, London. 